\title{
МЕДИКО-СОЦІАЛЬНЕ ДОСЛІДЖЕННЯ ДЛЯ ВИВЧЕННЯ СТАНУ ЛАБОРАТОРНОЇ СЛУЖБИ НА ТЕРИТОРІЇ М. КОВЕЛЯ І КОВЕЛЬСЬКОГО РАЙОНУ
}

\author{
А. Ю. Байцим \\ Ковельське діагностичне відділення центральної міської лікарні
}

У статті викладено результати соціологічного дослідження думки жителів м. Ковеля та Ковельського району, які є безпосередніми споживачами послуг лабораторно-діагностичної служби, про стан лабораторної діагностики.

\section{MEDICAL AND SOCIAL RESEARCH OF LABORATORY SERVICE IN KOVEL AND KOVEL DISTRICT}

\author{
A. Y. Baytsym \\ Kovel' diagnostic department of the central city hospital
}

The article presents the results of the sociological research of the views of residents of Kovel and Kovel district, which are direct consumers of laboratory and diagnostic services about the state of laboratory diagnostics.

Вступ. В останні роки перед системою охорони здоров'я стоїть завдання реформування з метою пошуку додаткових джерел фінансування, впровадження методів економічного управління, розробки та реалізації механізму захисту прав пацієнта для того, щоб усунути недоліки, які заважають поліпшенню охорони здоров'я населення [2].

Підвищення якості та доступності лабораторної діагностичної інформації та її ефективне використання в лікувально-діагностичному процесі, зокрема зниження витрат на виконання лабораторних досліджень за рахунок застосування високопродуктивного обладнання і збільшення доступності лабораторної діагностики для всіх жителів, незалежно від місця їх проживання, є актуальним завданням вдосконалення лабораторної служби [1, 3-5].

Одним із оціночних критеріїв якості медичної допомоги $є$ думка респондентів, в даному випадку, пацієнтів, які $\epsilon$ безпосередніми споживачами послуг лабораторно-діагностичної служби.

Основна частина. В соціологічному дослідженні брали участь 20 жителів м. Ковеля та Ковельського району у віковій категорії 18-24 років. Вони були поділені на 2 групи за гендерною ознакою по 10 осіб в

(c) А. Ю. Байцим, 2016 кожній. Питома вага міських жителів серед респондентів чоловічої статі склала 70 \%, сільських - 30 \% та, відповідно, 80 і 20 \% серед респондентів жіночої статі. У структурі респондентів-чоловіків частка працюючих становить 40 \%, безробітних - 10 \%, а найбільша питома вага припадає на студентів (50 \%). У структурі респондентів-жінок частка працюючих становить $20 \%$, домогосподарок - 20 \%, а найбільша питома вага також припадає на студентів (60 \%). Переважають респонденти зі спеціальною освітою, у тому числі вища освіта в $60 \%$, середньоспеціальна - у $30 \%$. У пацієнтів-жінок вища освіта була в 70 \%, середньоспеціальна - в 30 \%. При цьому 50 \% респондентівчоловіків оцінюють свій стан здоров'я як добрий, 20 \% як задовільний і 30 \% відзначають наявність хронічних захворювань. Щодо пацієнтів-жінок, то $60 \%$ оцінюють свій стан здоров'я як добрий, $10 \%$ - як задовільний і 30 \% відзначають наявність хронічних захворювань. Провідними критеріями при виборі клініко-діагностичної лабораторії пацієнтами $\epsilon$ такі, як вартість дослідження, достовірність дослідження та кваліфікація лікарів. Крім того, на вибір клінікодіагностичної лабораторії впливає відсутність черг, відстань від будинку та територіальна приналежність, але значно менше (табл.1). 
Таблиця 1. Розподіл критеріїв вибору клініко-діагностичної лабораторії населенням м. Ковеля і Ковельського району

\begin{tabular}{|l|c|c|}
\hline \multicolumn{1}{|c|}{ Критерії } & Чоловіки & Жінки \\
\hline Вартість дослідження & $30 \%$ & $30 \%$ \\
\hline Достовірність дослідження & $20 \%$ & $30 \%$ \\
\hline Кваліфікація лікарів лабораторії & $20 \%$ & $10 \%$ \\
\hline Відсутність черг & $10 \%$ & $10 \%$ \\
\hline Відстань від будинку & $10 \%$ & $10 \%$ \\
\hline Територіальна приналежність & $10 \%$ & $10 \%$ \\
\hline
\end{tabular}

Більшість респондентів звертається в лабораторію за рекомендацією лікуючого лікаря (60\% респондентівчоловіків та $70 \%$ респондентів-жінок). Близько третини пацієнтів (20\% респондентів-чоловіків та $30 \%$ респондентів-жінок) бачать необхідність у послугах лабораторії лише при виниклій необхідності.

Значна частина жителів м. Ковеля та Ковельського району у віковій категорії 18-24 років (90 $\%$ респондентів-чоловіків та респондентів-жінок) звертається за послугами лабораторної діагностики не часто. Так, більшість пацієнтів (80\% респондентівчоловіків та $70 \%$ респондентів-жінок) звертається до клініко-діагностичної лабораторії раз на рік, 10 \% респондентів-чоловіків та 20 \% респондентів-жінок раз на півріччя. Причинами нечастого користування населення лабораторними послугами $є$ відсутність лікарського направлення на обстеження (60\% респондентів-чоловіків та 70 \% респондентів-жінок), довгі черги (10\% респондентів-чоловіків та $10 \%$ респондентів-жінок), вартість лабораторних послуг (10\% респондентів-чоловіків та $10 \%$ респондентівжінок), трата часу на дорогу до лабораторії (20\% респондентів-чоловіків та $10 \%$ респондентів-жінок). Найбільшу перевагу респонденти віддають клінікодіагностичній лабораторії за місцем проживання (70\% респондентів-чоловіків та $60 \%$ респондентів-жінок). Майже половина респондентів (40 \%) оцінюють «задовільно» діяльність тієї лабораторії, куди звертаються, і третина (30 \%) - «добре». Незадоволеність роботою лабораторної служби у опитаного населення викликає вартість обстеження (50\%), рівень технічного оснащення (20\%) ійого сумнівна точність (20\%). Такий людський фактор, як неуважне ставлення медичних працівників клініко-діагностичної лабораторії (10\%), пацієнти вважають також значним. Не менш важливий і діапазон виконуваних лабораторних досліджень (30 \%), 20 \% населення відзначають наявність застарілого обладнання в лабораторії, де обслуговуються. 50 \% пацієнтів-чоловіків та 60 \% пацієнтів- жінок згідні проходити лабораторні дослідження за плату. Проте лише $20 \%$ респондентів-чоловіків та $40 \%$ респондентівжінок мають фінансову можливість оплачувати дорогі й високотехнологічні дослідження (визначення гормонів, онкомаркерів, маркерів вірусних інфекцій, захворювань сполучної тканини та ін.).

У числі пропозицій (табл. 2) перше місце займає доступність лабораторних послуг за рахунок зниження їх вартості (20 \% респондентів-чоловіків та 30 \% респондентів-жінок), друге - підвищення рівня матеріально-технічної бази лабораторнодіагностичної служби (20 \% респондентів-чоловіків та $20 \%$ респондентів-жінок), третє - введення пільг для деяких соціальних груп населення (насамперед, для студентів (20\% респондентів-чоловіків та $20 \%$ респондентів-жінок)).

Таблиця 2. Розподіл критеріїв пропозицій населення м. Ковеля і Ковельського району з покращення лабораторно-діагностичної служби

\begin{tabular}{|l|c|c|}
\hline \multicolumn{1}{|c|}{ Критерії } & Чоловіки & Жінки \\
\hline Знизити вартість лабораторних послуг, особливо, коштовних досліджень & $20 \%$ & $30 \%$ \\
\hline Підвищити рівень технічного оснащення & $20 \%$ & $20 \%$ \\
\hline Ввести пільги для окремих груп населення & $20 \%$ & $20 \%$ \\
\hline $\begin{array}{l}\text { Оптимізувати організацію праці медичного персоналу (збільшити } \\
\text { швидкість обслуговування) }\end{array}$ & $10 \%$ & - \\
\hline Підвищити оплату праці медичним працівникам & - & - \\
\hline Підвищити культуру обслуговування населення & $10 \%$ & $10 \%$ \\
\hline Підвищити професіоналізм медичних працівників & $10 \%$ & $10 \%$ \\
\hline Підвищити достовірність лабораторних досліджень & $10 \%$ & $10 \%$ \\
\hline
\end{tabular}


Висновки. 1. Для більшості респондентів у віковій категорії 18-24 років питання про вартість (доступність) дорогих лабораторних послуг має першорядне значення. 2. При виборі пацієнтами клініко-діагностичної лабораторії пріоритетними критеріями є: достовірність результатів, сучасний рівень оснащення, вартість досліджень, а також ква-

\section{ЛITEPATУPA}

1. Блажівська Р. Ф. Проблеми та перспективи розвитку лабораторної служби Львівської області / Р. Ф. Блажівська, О. О. Ястремська, Б. Д. Луцик // Лабораторна діагностика. - 2007. - № 1. - С. 53-55.

2. Развитие клинико-диагностической лаборатории с использованием новых экономических механизмов / Я. А. Накатис, О. А. Портной, А. А. Сапегин [и др.] // Клиническая больница. - 2015. - № 2 (12). - С. 15-18.

3. Толстанов О. К. Оцінка доступності лабораторної діагностики амбулаторними пацієнтами центральних ліфікація лікарів лабораторно-діагностичної служби. 3. Результати проведеного опитування дозволяють зробити висновок про доцільність пошуку шляхів вдосконалення діяльності лабораторно діагностичної служби, який підвищить задоволеність населення якістю медичної допомоги на території м. Ковеля і Ковельського району.

районних лікарень / О. К. Толстанов // Вісн. соц. гігієни та орг. охорони здоров'я України. - 2010. - № 2. - С. 31-34.

4. Цымбал Д. Е. Организация, менеджмент и экономика лабораторной службы областной детской больницы / Д. Е. Цымбал, Н. В. Архипова, Г. В. Коршунов // Клиническая лабораторная диагностика. - 2003. - № 9. - С. 11.

5. Шипова В. М. Оптимизация деятельности лабораторной службы лПУ / В. М. Шипова, И. Г. Пахомова // Главный врач. - 2010. - № 4. - С. 44-51. 